\title{
Foam Dosage Form
}

National Cancer Institute

\section{Source}

National Cancer Institute. Foam Dosage Form. NCI Thesaurus. Code C64898.

An aerated solution or suspension. 